\title{
Small Interfering RNA Targeting HIF-1a Reduces Hypoxia-Dependent Transcription and Radiosensitizes Hypoxic HT 1080 Human Fibrosarcoma Cells in vitro
}

\author{
Adrian Staab ${ }^{1,5}$, Markus Fleischer ${ }^{1,2}$, Juergen Loeffler ${ }^{2}$, Harun M. Said ${ }^{1}$, Astrid Katzer ${ }^{1}$, Christian Plathow ${ }^{3}$, \\ Herrmann Einsele ${ }^{2}$, Michael Flentje ${ }^{1}$, Dirk Vordermark ${ }^{1,4}$
}

\begin{abstract}
Background: Hypoxia inducible factor- 1 has been identified as a potential target to overcome hypoxia-induced radioresistance The aim of the present study was to investigate whether selective HIF-1 inhibition via small interfering RNA (siRNA) targeting hypoxia-inducible factor $1 \mathrm{a}$ (HIF-1a) affects hypoxia-induced radioresistance in HT 1080 human fibrosarcoma cells.

Material and Methods: HIF-1a expression in HT 1080 human fibrosarcoma cells in vitro was silenced using HIF-1a siRNA sequence primers. Quantitative real-time polymerase chain reaction assay was performed to quantify the mRNA expression of HIF1a. HIF-1a protein levels were studied by Western blotting at $20 \%$ (air) or after 12 hours at $0.1 \% \mathrm{O}_{2}$ (hypoxia). Cells were assayed for clonogenic survival after irradiation with 2,5, or $10 \mathrm{~Gy}$, under normoxic or hypoxic conditions in the presence of HIF-1a-targeted or control siRNA sequences. A modified oxygen enhancement ratio (OER') was calculated as the ratio of the doses to achieve the same survival at $0.1 \% \mathrm{O}_{2}$ as at ambient oxygen tensions. OER' was obtained at cell survival levels of $50 \%, 37 \%$, and $10 \%$.

Results: HIF-1a-targeted siRNA enhanced radiation treatment efficacy under severely hypoxic conditions compared to tumor cells treated with scrambled control siRNA. OER was reduced on all survival levels after treatment with HIF-1a-targeted siRNA, suggesting that inhibition of HIF-1 activation by using HIF-1a-targeted siRNA increases radiosensitivity of hypoxic tumor cells in vitro.

Conclusion: Inhibition of HIF-1 activation by using HIF-1a-targeted siRNA clearly acts synergistically with radiotherapy and increase radiosensitivity of hypoxic cells in vitro.
\end{abstract}

Key Words: Hypoxia inducible factor-1a $\cdot$ Small interfering RNA $\cdot$ Hypoxia $\cdot$ Radiation $\cdot$ Oxygen

Strahlenther Onkol 2011;187:252-9

DOI 10.1007/s00066-011-2167-0

Hypoxia-inducible-Factor-1a-Small-Interfering-RNA inhibiert die hypoxische Akkumulation von HIF-1 a und erhöht die Strahlensensitivität von HT-1080-Fibrosarkomzellen in vitro

Hintergrund und Ziel: Hypoxia-inducible Factor-1 (HIF-1) wurde als potentielles therapeutisches Target identifiziert. Ziel der Arbeit war es, zu untersuchen, ob die selektive HIF-1-Inhibition mittels Small Interfering RNA (siRNA) gegen HIF-1 a die Strahlensensibilität von hypoxischen HT-1080-Zellen beeinflussen kann.

Material und Methodik: Die HIF-1a-Expression in humanen HT-1080-Fibrosarkomzellen wurde mittels RNA-Interferenz nach Transfektion der Zellen mit siRNA unter hypoxischen Bedingungen $\left(0,1 \% \mathrm{O}_{2}, 12 \mathrm{~h}\right)$, bzw. Normoxie $\left(20 \% \mathrm{O}_{2}\right)$ in vitro inhibiert. Die HIF-1a-Genexpression wurde mit quantitativer Realtime-Polymerasekettenreaktion (qRT-PCR), das HIF-1a-Protein mittels Western Blot quantifiziert. Das klonogene Überleben wurde nach Bestrahlung unter Hypoxie und Normoxie bestimmt und daraus eine Oxygen Enhancement Ratio (OER') bei den Überlebensniveaus 50\%, 37\% and 10\% berechnet.

Resultate: HIF-1a-siRNA erhöht die Strahlensensibilität unter hypoxischen Bedingen, verglichen mit HT-1080-Zellen, die mit Kontroll-siRNA behandelt wurden. Die OER' war bei allen Überlebensniveaus reduziert.

Schlussfolgerung: Eine selektive Inhibition der HIF-1-Aktivierung durch HIF-1a-siRNA wirkt synergistisch mit einer Bestrahlung und erhöht die Strahlensensitivität hypoxischer Tumorzellen in vitro.

Schlüsselwörter: Hypoxia-inducible factor-1a·Small Interfering RNA · Hypoxie · Bestrahlung · Sauerstoff

\footnotetext{
'Department of Radiation Oncology, University of Würzburg, Germany,

${ }^{2}$ Medical Clinic II, University of Würzburg, Germany,

${ }^{3}$ Department of Nuclear Medicine, University of Freiburg, Germany,

${ }^{4}$ Department of Radiation Oncology, Martin Luther University Halle-Wittenberg, Germany,

${ }^{5}$ Paul Scherrer Institute, Villigen, Switzerland.
}

Received: April 26, 2010; accepted: January 24, 2011

Published Online: March 25, 2011 


\section{Background}

Hypoxia is a common feature of solid tumors that profoundly affects the biological behavior, response to therapy, and prognosis of human cancers $[10,31]$. Despite of improvements in chemo- and radiotherapy, long-term prognosis is still poor for many patients with newly diagnosed or recurrent cancer diseases [3, 28, 36, 38].

Several reports have demonstrated an increased chemoresistance $[4,5]$ and radioresistance [21] in hypoxic tumor cells resulting from activation of the hypoxia-inducible factor-1 (HIF-1) pathway. The HIF-1 system is a key regulator of a broad range of cellular and systemic responses to hypoxia and acts in all mammalian cells.

The transcription factor HIF-1 is a heterodimer formed by the association of an oxygen-regulated HIF-1 $1 \alpha$ subunit with a constitutively expressed HIF-1 $\beta$ subunit $[22,34]$. Degradation of HIF- $1 \alpha$ is $\mathrm{O}_{2}$ dependent. Under normoxic conditions, HIF$1 \alpha$ is degraded by the activity of prolyl hydroxylases $[12,13]$. Under hypoxic conditions, the rates of hydroxylation and ubiquitination decline, resulting in an accumulation of HIF-1 $\alpha$ [7].

Associations between high levels of protein expression of HIF-1a in tumor tissues [30] and poor prognosis have been shown in patients with breast cancer [29], head and neck cancer [1,14] cervical cancer [6], esophagus [20], stomach [9], and non-small cell lung cancer [17]. Increased expression of HIF1 a protein is, therefore, an independent predictor of poor prognosis and poor response to treatment in most types of cancer. In particular, high expression of HIF-1 $\alpha$ or HIF-1-regulated proteins, such as glucose transporter 1 (GLUT-1) or carbonic anhydrase IX (CA IX), is associated in most series not only with survival endpoints but also with locoregional control after radical radiotherapy, suggesting a direct link between the expression of these proteins and hypoxia-related radioresistance of tumor cells [2]. We were previously able to show in HT 1080 human fibrosarcoma cells that targeting HIF-1 function pharmacologically with chetomin sensitized hypoxic cells to singledose radiotherapy. However, this approach was impaired by relevant cytotoxicity of the agent and a rather unspecific action of the compound inhibiting the interaction of HIF-1 and the transcriptional coactivator p300 [25]. The aim of the present study was to investigate if selective HIF-1 inhibition by using small interfering RNA (siRNA) targeting HIF-1a affects hypoxiainduced radioresistance in human tumor cells.

\section{Material and Methods}

\section{Cell Culture}

Early-passage HT 1080 human fibrosarcoma cells from the American Type Culture Collection (ATCC, Rockville, MD) were maintained under standard conditions as previously described [32]. Cells were cultured in MEM supplemented with $10 \%$ fetal bovine serum and 100,000 U/L penicillin and $100 \mathrm{mg} / \mathrm{L}$ streptomycin (all from Sigma, St. Louis, MO, USA) with $5 \% \mathrm{CO}_{2}$ in a well-humidified incubator. For hypoxia experiments, early-passage cells were split and seeded into 80-mm glass Petri dishes at $1.0 \times 10^{6}$ cells per dish. On the following day, when the cells were still in the exponential growth phase, they were transferred without further medium change to a Ruskinn (Cincinnati, OH, USA) Invivo2 hypoxic workstation for hypoxia treatment. The oxygen concentration of $0.1 \%$ was achieved inside the workstation before transferring the cells by calibrating the oxygen probe against air according to the manufacturer's instructions; adjusting the instrument settings to the desired $\mathrm{O}_{2}$ concentration, $5 \% \mathrm{CO}_{2}$ and $37^{\circ} \mathrm{C}$; and subsequent flooding of the chamber with an appropriate gas mixture of pressurized air, $\mathrm{N}_{2}$, and $\mathrm{CO}_{2}$ through an automated gas mixing module. Aerobic conditions were maintained in the incubator at $5 \% \mathrm{CO}_{2}$ and $20 \% \mathrm{O}_{2}$. Where indicated siRNA against HIF-1 $\alpha$ (Qiagen, Hilden, Germany) was used.

Different siRNAs were assayed in pilot flow cytometry experiments. In RT-PCR and clonogenic survival experiments, siRNA was added at a concentration of $133 \mathrm{nM}$ to medium 4 hours before treatment with hypoxia. Then after 4 hours, when HT 1080 cells became adherent, HT 1080 cells were transferred to the hypoxic workstation $\left(0.1 \% \mathrm{O}_{2}, 12\right.$ hours $)$ or to the well-humidified incubator ( 12 hours) without changing medium. HT 1080 cells were, thus, treated for 16 hours with siRNA $(133 \mathrm{nM})$ prior to radiation treatment.

Flow Cytometry of 5HRE-hCMVmp-EGFP HT 1080 Cells To study the effect of different HIF-1 $\alpha$-targeted or control siRNA sequences on hypoxia-responsive element (HRE) binding of HIF- 1 and gene transactivation, we used HT 1080 cells stably transfected with enhanced green fluorescent protein (EGFP) under the control of a hypoxia-responsive promoter containing five copies of a hypoxia-responsive element from the human vascular endothelial growth factor (VEGF) gene. HT 1080 cells transfected with the same EGFP under the control of a strong constitutive, hypoxia-independent CMV promoter were used as positive controls as described previously (both cell types kindly provided by J.M. Brown, Stanford University, CA, USA) [32]. The design of the constructs and their application as a reporter system of tumor hypoxia has been previously reported [23].

Cells were exposed to experimental conditions as for PCR experiments in glass Petri dishes. Due to the known requirement of sufficient reoxygenation for the development of hypoxia-dependent, HRE-mediated EGFP fluorescence, all samples were returned to aerobic conditions in the incubator for 4 hours before FACS analysis as previously described [32]. EGFP fluorescence was measured on a FacsCalibur flow cytometer (Becton Dickinson) as described previously [2]. Dead cells and debris were gated out on the basis of forward and side scatter dot plots.

\section{RT-PCR}

Quantitative real-time polymerase chain reaction (RT-PCR) assay was performed using the LightCycler instrument and the SybrGreen detection system (both from Roche Diagnostics, 
Mannheim, Germany) to quantify the mRNA expression of HIF-1 $\alpha$. Total RNA was purified from $1.0 \times 10^{6} \mathrm{HT} 1080$ cells with use of RNeasy Mini kit (Qiagen, Hilden, Germany) according to the manufacturer's instructions. RNA was eluted in $30 \mu \mathrm{l}$ RNase-free water.

First-strand cDNA was synthesized from $900 \mathrm{ng}$ total RNA with use of Quantitect Reverse Trancriptase Kit (Qiagen) according to the protocol of the manufacturer.

For the amplicon detection, the LightCycler Sybr-Green kit (Roche Diagnostics, Mannheim, Germany) was used and supplemented with $4 \mathrm{mM} \mathrm{MgCl} 2$ and $0.5 \mu \mathrm{M}$ (each) of the HIF-1 $\alpha$-specific primers (5'-CTC AAA GTC GGA CAG CCT CA-3', 5'-CCC TGC AGT AGG TTT CTG CT-3'). PCR was carried out in $20-\mu \mathrm{l}$ capillaries $(2 \mu \mathrm{l} / 4 \mu \mathrm{g}$ of cDNA and $18 \mathrm{ml}$ of master-mix) at $95^{\circ} \mathrm{C}$ for $30 \mathrm{~s}$, followed by 50 cycles of $15 \mathrm{~s}$ at $50{ }^{\circ} \mathrm{C}, 15 \mathrm{~s}$ at $72{ }^{\circ} \mathrm{C}$. Genotyping was performed by melting curve analysis: $50^{\circ} \mathrm{C}$ for $15 \mathrm{~s}$, followed by a temperature increase from $50{ }^{\circ} \mathrm{C}$ to $95^{\circ} \mathrm{C}\left(0.2^{\circ} \mathrm{C} / \mathrm{s}\right)$ with continuous fluorescence recording on channel $\mathrm{F} 1$. Each assay run included a reagent control containing water instead of sample cDNA. All assays were performed in three replicates. For normalization, we used the $\beta 2$-microglobulin housekeeping gene set (Roche Diagnostics). Amplification was carried out by using the FastStart Master Hybridization Probes kit (Roche Diagnostics) with the following parameters: $95^{\circ} \mathrm{C}$ for $9 \mathrm{~s}, 55^{\circ} \mathrm{C}$ for $15 \mathrm{~s}, 72{ }^{\circ} \mathrm{C}$ for $20 \mathrm{~s}$. 45 cycles were performed. The control sample consisting of unstimulated cells under normoxia was set to be 1. Cells under hypoxia, stimulated with HIF-1 $\alpha-$ targeted or control siRNA, were compared with the control sample.

\section{Small Interfering RNA (siRNA) Treatment and}

Transfection

Approximately $1.0 \times 10^{6}$ HT-1080 carcinoma cells were gently resuspended in $100 \mu \mathrm{l}$ MEM at room temperature. HT 1080 cells were electroporated (Elektroporations-Impulsgenerator 0-2500 V (EPI 2500) (Dr. Fischer, Heidelberg, Germany) with $133 \mathrm{nM}$ double-stranded antisense oligonucleotides specific for HIF-1 a mRNA. A protein expression analysis, gene expression analysis, FACS analysis and in vitro clonogenic assay were all performed 16 hours after siRNA transfection.

HIF-1 $\alpha$ expression was silenced using designed HIF-1a siRNA sequence primers (Qiagen, Hilden, Germany) that were transfected into HT 1080 cells according to the manufacturer's instructions. Briefly, HIF-1 $\alpha$-targeted or control siRNA sequences were added to HT 1080 cells at a final concentration of $133 \mathrm{nM}$, (siRNA3: HIF- $1 a$ sense (CCA UUU ACA UAA UAU AGA A)dTdt targeting AGC CAT TTA CAT AAT ATA GAA of the human HIF-1 $a$ mRNA. siRNA4: HIF-1 1 sense r(CCG AAU UGA UGG GAU AUG A)dTdt targeting TAC CGA ATT GAT GGG ATA TGA of the human HIF-1a mRNA)).

Cells transfected with scrambled control siRNA (Qiagen: AllStars Neg. Control siRNA, Catalog no. 1027281) were used as a negative control.

\section{Radiation Treatment and Clonogenic Assay}

Immediately after the 12-hour hypoxia treatment or control treatment ( \pm siRNA133 nM), the glass culture dishes were enclosed in Perspex shells inside the hypoxic workstation and transferred to the linear accelerator. Cells were irradiated with a dose of 2, 5, or $10 \mathrm{~Gy}$ (dose rate $2.5 \mathrm{~Gy} / \mathrm{min}, 6 \mathrm{MV}$ photons, room temperature, adequate Perspex bolus). Aerobic cells were irradiated in similar Perspex shells with holes permitting unimpaired air exchange. Cell survival was quantified by standardized colony-forming assay. HT 1080 cells from untreated or irradiated monolayers were trypsinized and resuspended immediately after treatment, seeded in culture flasks in appropriate dilutions. On day 14, cells were stained with crystal violet, and colonies consisting of at least 50 cells were counted. The plating efficiency (PE) was expressed as the percentage of colonies relative to the number of cells seeded. The ratio of $\mathrm{PE}$ of irradiated and respective control cells, correcting for differences in plating efficiency of unirradiated cells, gave the relative survival (S). Survival curves were generated by plotting $S$ as a function of radiation dose (D). The survival data were fitted with the linear-quadratic model: $S(D)=\exp [-(\alpha \mathrm{D}+\beta \mathrm{D} 2)]$ by optimizing variable parameters $\alpha$ and $\beta$ [10]. A modified oxygen enhancement ratio (OER') was calculated as the ratio of the doses to achieve the same survival at $0.1 \% \mathrm{O}_{2}$ as at ambient oxygen tensions: OER' = Dhypoxia/Dnormoxia. OER' was obtained at cell survival levels of $50 \%, 37 \%$, and $10 \%$.

\section{Western Blot Analysis}

At the end of the 16-hour in vitro treatment under different conditions, Petri dishes were immediately placed on ice. HIF$1 \alpha$ protein and $\beta$-tubulin protein were quantified in Western blots of nuclear extracts as previously described [31]. For quantification of HIF- $1 \alpha$ protein content, the ratio of HIF- $1 \alpha$ and $\beta$-tubulin band densities of a control sample transfected with scrambled control siRNA under hypoxic conditions $\left(0.1 \% \mathrm{O}_{2}\right.$, 12 hours) HT 1080 cells, aliquots of which were run with each blot, were defined as $100 \%$ and used as a reference for quantification. Means \pm standard deviations (SD) were calculated for each condition.

\section{Statistical Analysis}

Expression levels of mRNA and clonogenic survival were compared between treatment groups by Mann-Whitney U test using Statistica vs. 6.1 (Statsoft, Tulsa, OK, USA) software ( $\mathrm{p}<0.05$ considered significant).

\section{Results}

Effects of HIF-1 -Targeted siRNA (siRNA 3 and siRNA4) on HIF1 a mRNA Expression

Transfection of HT 1080 tumor cells with HIF-1a-targeted siRNA (siRNA3 and siRNA4) caused a significantly reduced expression of HIF- 1 a mRNA compared to untreated control cells and HT 1080 cells transfected with scrambled control siRNA (Figure 1). The mean HIF-1 $\alpha$ mRNA expression was reduced 


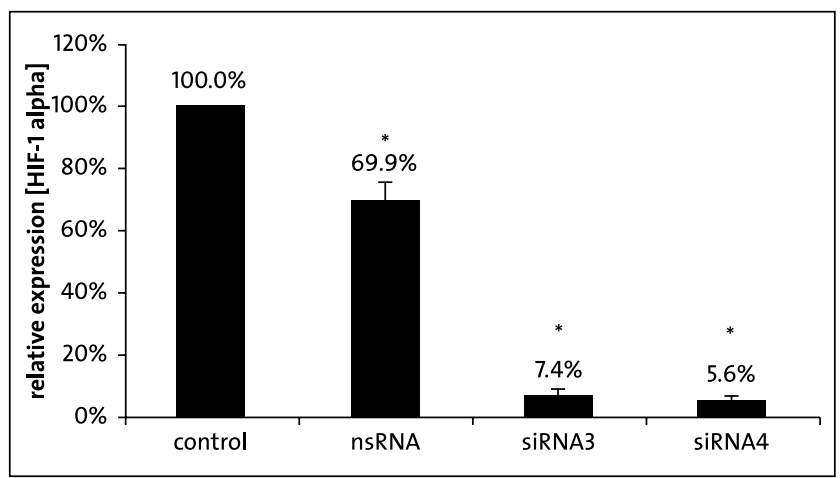

Figure 1. Downregulation of HIF-1 $\alpha$ mRNA expression by HIF-1 $\alpha$ targeted siRNA in HT 1080 human fibrosarcoma cells. Quantitative RTPCR was performed to quantify the expression of the HIF-1 $\alpha$ gene $(n=3$, mean \pm SEM). Expression of HIF- $1 \alpha$ mRNA was measured 16 hours after transfection of HT 1080 tumor cells with HIF-1 $\alpha$-targeted siRNA (siRNA3 and siRNA4) or scrambled control siRNA (nsRNA). Untreated HT 1080 control cells were defined as $100 \%$ and used as a reference for quantification. Tansfection of HT 1080 cells with HIF- $1 \alpha$-targeted siRNA (siRNA 3 and siRNA4) and scrambled control siRNA caused a reduced expression of the HIF- $\alpha$ mRNA (mean \pm SEM of $n=3,{ }^{*} p<0.05$ ). HIF- $1 \alpha$ gene expression in HT 1080 cells transfected with HIF- $1 \alpha$-targeted siRNA (siRNA 3 and siRNA4) was also significantly reduced compared to HT 1080 cells transfected with scrambled control siRNA.

Abbildung 1. Herunterregulation der HIF-1 $\alpha$-mRNA-Expression durch HIF-1 $\alpha$-targeted siRNA in humanen HT-1080-Fibrosarkomzellen. Die HIF-1 $\alpha$-Genexpression wurde mit einer quantitativen Real-time-Polymerasekettenreaktion bestimmt $(n=3$, mean $\pm S E)$. Die HIF-1 $\alpha$-mRNAExpression wurde bestimmmt 16 Stunden nach Transfektion der HT1080-Tumorzellen mit HIF-1 $\alpha$-targeted siRNA (siRNA3 and siRNA4) oder Kontrol siRNA (nsRNA). Unbehandelte HT-1080-Zellen wurden als Referenz (100\%) zur Quantifkation definiert. Transfektion der HT-1080-Zellen mit HIF-1 $\alpha$-targeted siRNA (siRNA3 and siRNA4) und Kontroll-siRNA (ns siRNA) verursacht eine reduzierte HIF- $\alpha$-mRNA-Expresssion (Mittelwert $\left.\pm \mathrm{SE}, \mathrm{n}=3,{ }^{*} \mathrm{p}<0.05\right)$. Die HIF-1 $\alpha$-Gen-Expression in HIF-1 $\alpha$-targetedsiRNA-(siRNA3 und siRNA4-)transfizierten Zellen war signifikant reduziert verglichen mit Kontroll-siRNA-(nsRNA-)transfizierten HAT-1080Zellen (Mittelwert $\pm S E, n=3,{ }^{*} p<0.05$ ).

after transfection with scrambled siRNA to $69.9 \pm 5.7 \%$ compared to untreated HT 1080 cells (100\%). Transfection with siRNA3 or siRNA4 reduced the mean \pm SD HIF- $1 \alpha$ mRNA expression to $7.4 \pm 1.9 \%$ and $5.6 \pm 1.5 \%$, respectively, compared to the untreated control (100\%).

\section{Effects of siRNA on HIF-1-Dependent Transcriptional Activation}

Transfection of HT 1080 cells with HIF-1 $\alpha$-targeted siRNA (siRNA3 and 4) inhibited the hypoxic activation of HRE-mediated EGFP fluorescence in stably transfected HT $1080 \mathrm{hu}$ man fibrosarcoma cells (Figure 2). A maximum suppression of EGFP fluorescence signal was measured when HT 1080 cells were transfected with siRNA3 and siRNA4 4-8 hours prior to hypoxia treatment $\left(0.1 \% \mathrm{O}_{2}, 12\right.$ hours $)$ and at a final concentration of $133 \mathrm{nM}$ (data not shown).

siRNA3 suppressed the hypoxic increase in EGFP fluorescence significantly to $31.5 \% \pm 1.4 \%$ compared to the hypoxic

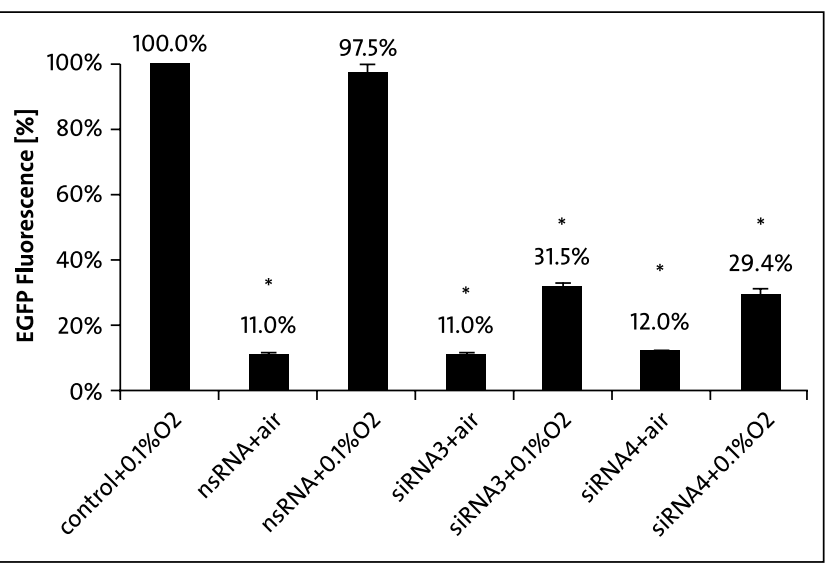

Figure 2. Effects of siRNA on HIF-1-dependent transcriptional activation in HT 1080 human fibrosarcoma cells. HT 1080 human fibrosarcoma cells were pre-treated with $133 \mathrm{nM}$ small interfering RNA for 4 hours and transferred for 12 hours to hypoxic $\left(0.1 \% \mathrm{O}_{2}\right)$ or maintained in aerobic $\left(20 \% \mathrm{O}_{2}\right)$ conditions.Transfection HT 1080 cells with HIF- $1 \alpha$-targeted siRNA (siRNA3 and siRNA4) inhibits the hypoxic activation of HRE-mediated EGFP fluorescence in stably transfected HT 1080 human fibrosarcoma cells. Hypoxic HT 1080 control cells were defined as $100 \%$ and used as a reference for quantification (mean \pm SEM of $n=3$, *significant difference from hypoxic control, $\mathrm{p}<0.05)$.

Abbildung 2. Einfluss von siRNA auf die HIF-1-abhängige transkriptionelle Aktivierung in humanen HAT-1080-Fibrosarkomzellen. Humane HAT-1080-Fibrosarkom-Zellen wurden 4 Stunden lang mit 133 nM Small Interfering RNA vorbehandelt und anschließend 12 Stunden lang unter hypoxischen $\left(0,1 \% \mathrm{O}_{2}\right)$ bzw. aeroben $\left(20 \% \mathrm{O}_{2}\right)$ Bedingungen inkubiert. Transfektion der HAT-1080-Zellen mit HIF-1 $\alpha$-targeted siRNA (siRNA3 and siRNA4) inhibiert die hypoxische Aktivierung des HIF-1-regulierten Promotors und "green fluorescent protein" (GFP) als Marker (5HRE-GFP) in stabil transfizierten humanen HT-1080-Fibrosarkomzellen. Hypoxische HAT-1080-Kontrollzellen wurden definert als $100 \%$ und wurde als Referenz zur Quantifikation verwendet (Mittelwert $\pm S E, n=3$, *signifikanter Unterschied $p<0,05$ )

control (100\%). The mean hypoxic EGFP fluorescence was suppressed to $29.4 \% \pm 1.6 \%$ of the hypoxic control $(100 \%)$ after transfection with siRNA4. Cells transfected with scrambled control siRNA (nsRNA) exhibited no relevant suppression of hypoxic EGFP fluorescence signal $(97.5 \% \pm 2.8 \%)$ compared to the hypoxic control (100\%). Control cells or cells transfected with either scrambled control siRNA (nsRNA) or HIF-1atargeted siRNA (siRNA3 and siRNA4) showed only basal EGFP fluorescence below $15 \%$ under aerobic conditions compared to the hypoxic control (100\%).

\section{Down-Regulation of HIF-1 $\alpha$ Protein in HT 1080 Cells by} Small Interfering RNA

Under normoxic conditions, low basal expression of HIF-1a protein was measured. Increased HIF-1a protein expression was observed under hypoxia $\left(0.1 \% \mathrm{O}_{2}, 12\right.$ hours; Figure 3$)$. In HT 1080 cells, the mean hypoxic HIF-1 $\alpha$ accumulation during severe hypoxia was significantly reduced to $47.1 \% \pm 9.1 \%$ after transfection HT 1080 cells with siRNA3 and to $35.3 \% \pm 4.1 \%$ after transfection HT 1080 cells with siRNA4 compared to hypoxic 


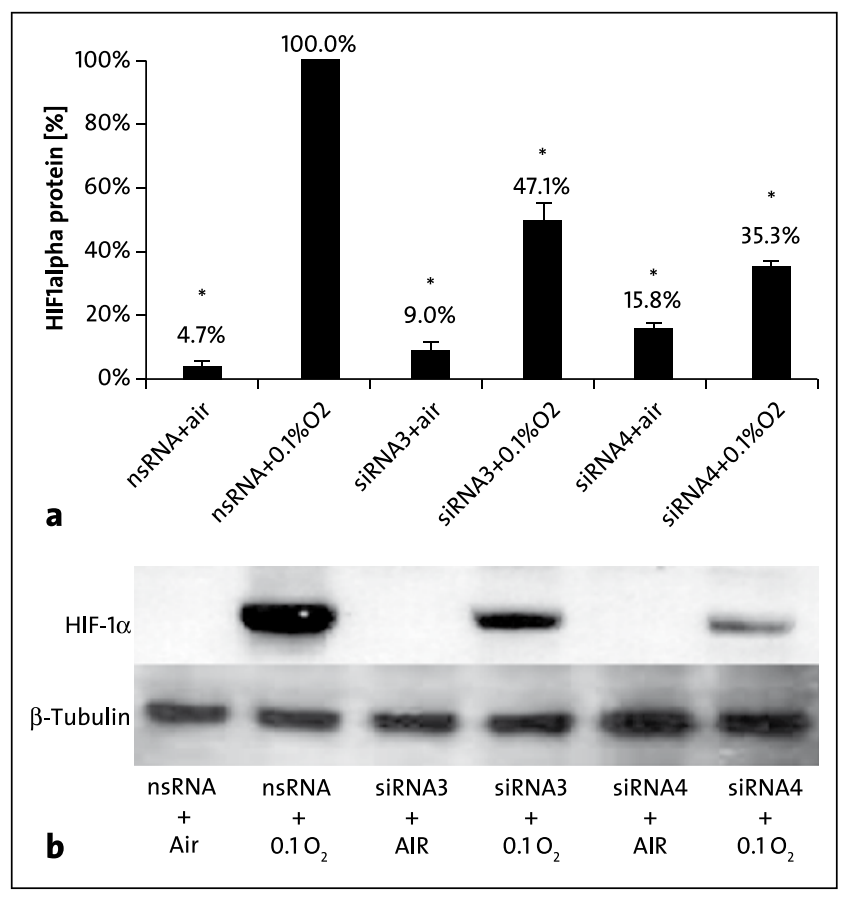

Figure $\mathbf{3 a}$ and $\mathbf{3 b}$. Downregulation of HIF- $1 \alpha$ protein levels by small interfering RNA in HT 1080 human fibrosarcoma cells. HT 1080 human fibrosarcoma cells were pre-treated with $133 \mathrm{nM}$ small interfering RNA for 4 hours and transferred for 12 hours to hypoxic $\left(0.1 \% \mathrm{O}_{2}\right)$ or maintained in aerobic $\left(20 \% \mathrm{O}_{2}\right)$ conditions. HIF-1 $\alpha$ levels were evaluated by Western blot (a mean \pm SEM of $n=5$, * significant difference at $p<0.05$ ). Cells transfected with scrambled control siRNA (nsRNA) under hypoxic conditions were defined as $100 \%$ and used as a reference for quantification. Transfection HT 1080 cells with HIF- $1 \alpha$-targeted siRNA (siRNA3 and siRNA4) caused a reduced hypoxic accumulation of HIF-1 $\alpha$ protein. Representative Western blot (b).

Abbildung 3a und 3b. Herunterregulation des HIF-1 $\alpha$-Proteins in humanen HAT-1080-Fibrosarkomzellen durch Small Interfering RNA. Humane HAT-1080-Fibrosarkom-Zellen wurden 4 Stunden lang mit 133 nM Small Interfering RNA vorbehandelt und anschließend 12 Stunden lang unter hypoxischen $\left(0,1 \% \mathrm{O}_{2}\right)$ bzw. aeroben $\left(20 \% \mathrm{O}_{2}\right)$ Bedingungen inkubiert. HIF-1 $\alpha$-Protein wurde mit Western Blot detektiert. Transfektion der HAT1080-Zellen mit HIF-1 $\alpha$-targeted siRNA (siRNA3 and 4) verursacht eine reduzierte hypoxische Akkumulation von HIF-1 $\alpha$. Mit Kontroll-siRNA transfizierte hypoxische HAT-1080-Zellen, wurden als $100 \%$ definiert und als Referenz zur Quantifikation verwendet (a Mittelwert $\pm \mathrm{SE}, \mathrm{n}=5$, * $\mathrm{si}$ gnifikanter Unterschied $p<0,05)$. Repräsentativer Western Blot (b).

control HT 1080 tumor cells (100\%) transfected with scrambled control siRNA (ns siRNA, $0.1 \% \mathrm{O}_{2} ; \mathrm{p}<0.05$ ).

\section{Clonogenic Survival}

Treatment ofHT 1080 cellswith HIF-1 $\alpha$-targetedsiRNA(siRNA3 and siRNA4) in a concentration of $133 \mathrm{nM}$ or scrambled control siRNA (nsRNA) did not significantly affect the survival fraction under normoxic or under hypoxic conditions (Figure 4). Scrambled control siRNA also did not affect the clongenic survival and has no effect on the radiosensitivity of HT 1080 cells in air compared to nontransfected HT 1080 cells (Figure 5).

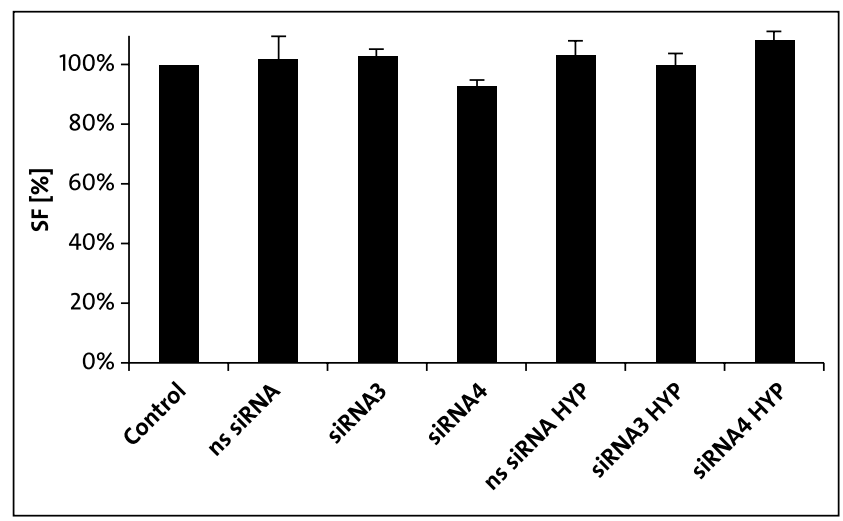

Figure 4. Survival Fraction (SF) under normoxic conditions or under hypoxic conditions after treatment with HIF- $1 \alpha$-targeted siRNA in HT 1080 human fibrosarcoma cells. Effects of treatment with in vitro hypoxia $(0.1 \%$ $\mathrm{O}_{2}$ ) and/or HIF-1 $\alpha$-targeted siRNA (siRNA3 and siRNA4) or scrambled control siRNA (nsRNA) on the survival fraction (SF) of HT 1080 human fibrosarcoma cells. SF of untreated HT 1080 human fibrosarcoma cells incubated under normoxic condition were defined as $100 \%$ and used as a reference for quantification. (mean \pm SEM of $n=3$, * significant difference between respective HIF- $1 \alpha$-targeted siRNA [siRNA3 and siRNA4] or scrambled control siRNA [nsRNA]).

Abbildung 4. Survival Fraction (SF) in humanen HAT-1080-Fibrosarkomzellen unter normoxischen oder hypoxischen Bedingungen nach Behandlung mit HIF- $1 \alpha$-targeted siRNA. Der Einfluss von Hypoxie in vitro $\left(0-1 \% \mathrm{O}_{2}\right)$ und/oder HIF-1 $\alpha$-targeted siRNA (siRNA3 und siRNA4) oder Kontroll-siRNA (nsRNA) auf die Survival Fraction (SF) von humanen HAT-1080-Fibrosarkomzellen. Die SF von unbehandelten humanen HAT-1080-Fibrosarkomzellen, welche unter normoxischen Bedingungen inkubiert wurden, wurde als $100 \%$ definiert und diente als Referenz zur Quantifizierung (Mittelwert $\pm S E, n=3$, *signifikanter Unterschied zwischen HIF- $1 \alpha$-targeted siRNA [siRNA3 and siRNA4] bzw. Kontroll-siRNA [nsRNA]; $\mathrm{p}<0,05)$.

In the absence of siRNA3 and siRNA4, survival after single-dose irradiation was significantly increased under hypoxic conditions compared to normoxia $(\mathrm{p}<0.05)$. HIF-1 $\alpha$-targeted siRNA (siRNA3 and siRNA4) enhanced significantly radiation treatment efficacy under severely hypoxic conditions compared to tumor cells treated with scrambled control siRNA (ns siRNA) (Figure 6, Table 1).

OER' was calculated at $50 \%, 37 \%$, and $10 \%$ survival levels obtained from calculated $\alpha$ and $\beta$ values. For three independent experiments, the mean OER' values were calculated. The reduction of OER' values was significant on all survival levels after treatment with HIF-1 $\alpha$-targeted siRNA (siRNA3 and siRNA4), except for the survival level $10 \%$ after incubation with siRNA4 (Table 2).

\section{Discussion}

HIF-1 inhibition has been shown to slow tumor growth in in vitro and in vivo tumor models $[16,39]$ and to act synergistically with other treatment modalities such as radiotherapy [25]. Kung et al. [16] identified chetomin as a small molecule blocking the HIF pathway. Chetomin disrupts the structure of the $\mathrm{CH} 1$ domain of $\mathrm{p} 300$, a transcriptional coactivator, thereby, 


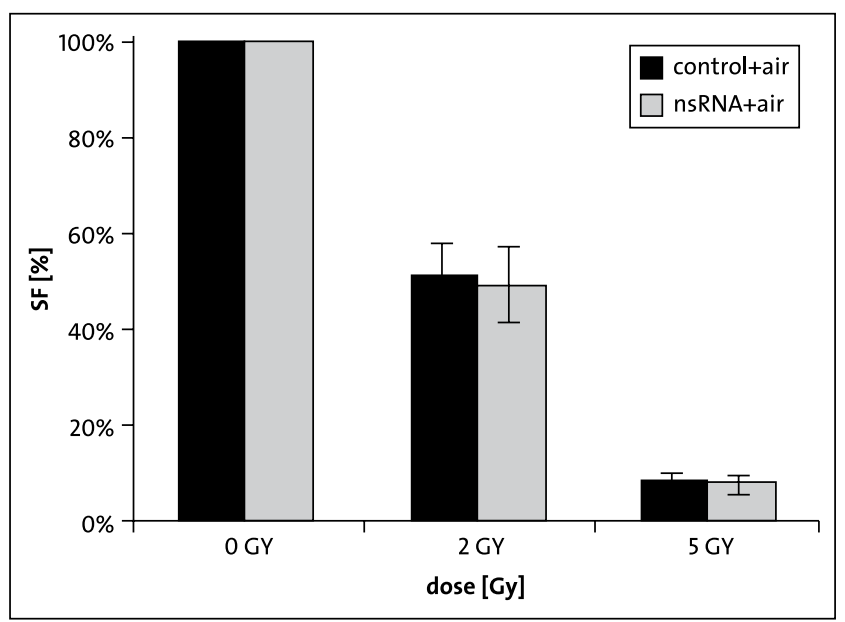

Figure 5. Clonogenic survival after treatment with/without scrambled control siRNA (nsRNA) under normoxic conditions in HT 1080 human fibrosarcoma cells. Clonogenic survival of HT 1080 human fibrosarcoma cells after radiation treatment in air $\left(20 \% \mathrm{O}_{2}\right)$ : HT 1080 cells were transfected with scrambled control siRNA (nsRNA) 16 hours prior radiation treatment $(n=3$, mean \pm SEM). Scrambled control siRNA ( $n$ sRNA) has no effect on the radiosensitivity of HT 1080 cells in air compared to nontransfected HT 1080 cells.

Abbildung 5. Klonogene Überleben in humanen HAT-1080-Fibrosarkomzellen nach Behandlung der Zellen mit/ohne Kontroll-siRNA (nsRNA) unter normoxischen Bedingungen $\left(20 \% \mathrm{O}_{2}\right)$. Klonogenes Überleben von humanen HAT-1080-Fibrosarkom-Zellen nach Bestrahlung unter normoxischen Bedingungen $\left(20 \% \mathrm{O}_{2}\right)$. HAT-1080-Zellen wurde mit KontrollsiRNA transfiziert $(n=3$, Mittelwert $\pm S E$ ) und nachfolgend 16 Stunden lang unter normoxischen Bedingungen inkubiert. Anschließend wurden die Zellen bestrahlt. Kontroll-siRNA (nsRNA) beeinflusst nicht die Strahlensensitivität von HAT-1080-Zellen unter normoxischen Bedingungen $\left(20 \% \mathrm{O}_{2}\right)$ verglichen mit unbehandelten, d.h. nicht transfizierten HAT-1080-Zellen.

precluding its interaction with HIF and attenuating hypoxiainducible transcription. We previously showed in a human fibrosarcoma cell line that indirect HIF-1 targeting with chetomin suppresses the transcriptional response to hypoxia and reduces hypoxic radioresistance in vitro [25].

Lövey et al. [18] could also show in A431 tumor-bearing SCID mice treated rHuEPOalpha a decreased tumoral HIFlalpha expression and an increased the efficacy of radiotherapy in vivo. In the present study, we investigated the effects of direct, specific targeting of HIF-1 $\alpha$ via RNA interference under conditions of radiobiologically relevant tumor hypoxia. HIF- $1 \alpha$ expression was silenced using two differently designed HIF- $1 \alpha-$ targeted siRNAs (siRNA3 and siRNA4) that were transfected into HT 1080 cells. We could demonstrate that knockdown of hypoxia-induced expression of HIF-1 $\alpha$ with RNA interference increased radiosensitivity of hypoxic cells and strongly suppressed HIF-1a m-RNA expression compared to untreated human fibrosarcoma cells or HT 1080 cells treated with scrambled control siRNA.

The calculated modified oxygen enhancement ratio (OER') values were reduced after incubation with chetomin
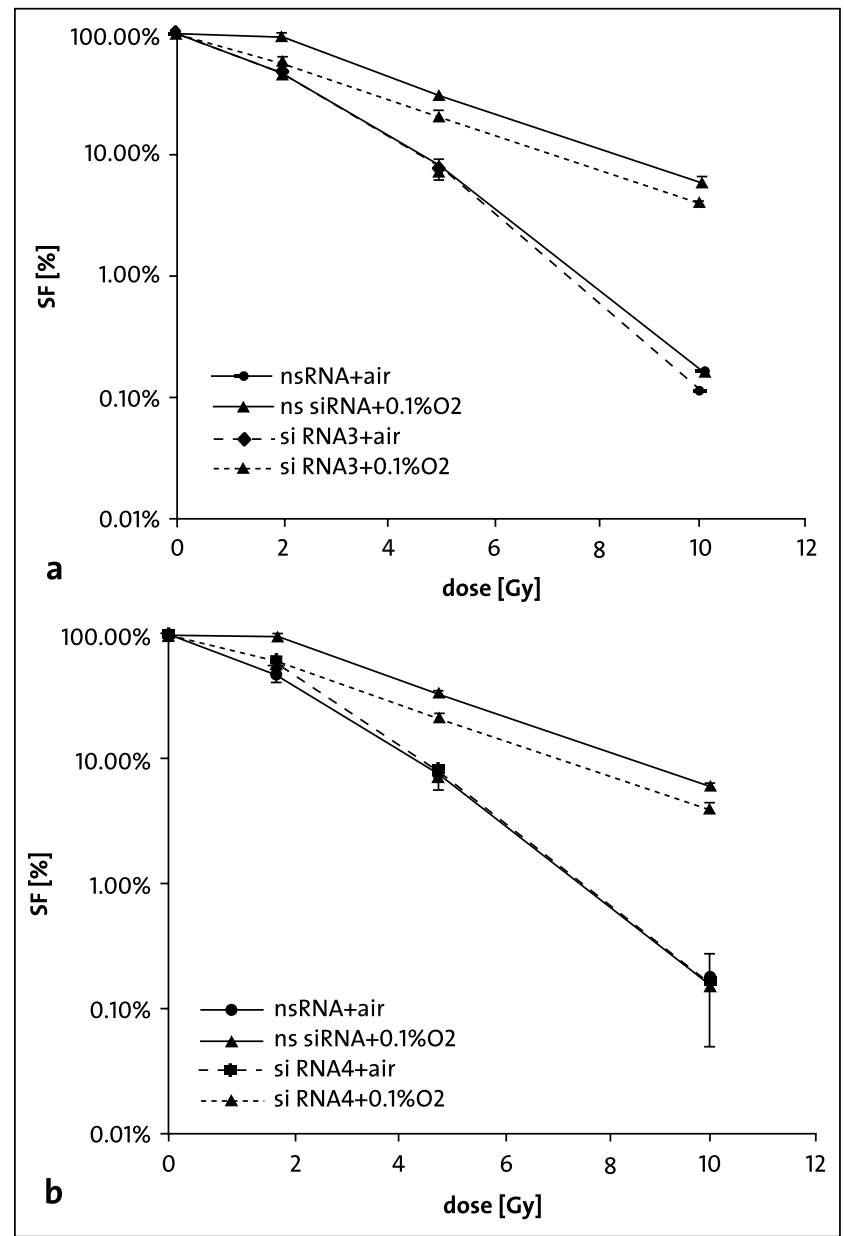

Figure $\mathbf{6 a}$ and $\mathbf{6 b}$. Clonogenic survival after treatment with HIF-1 $\alpha-$ targeted siRNA under normoxic and hypoxic conditions in HT 1080 human fibrosarcoma cells. Clonogenic survival of HT 1080 human fibrosarcoma cells after radiation treatment in air $\left(20 \% \mathrm{O}_{2}\right)$ or hypoxia $(0.1 \%$ $\mathrm{O}_{2}$ ): $\mathrm{HT} 108$ cells were transfected with HIF- $1 \alpha$-targeted siRNA (a siRNA3, b siRNA4) or scrambled control siRNA (nsRNA) 4 hours prior to hypoxia $(n=3$, mean \pm SEM). HT 1080 cells were cultured for 12 hours under hypoxia/normoxia and in the presence of $133 \mathrm{nM} \mathrm{HIF-1} \alpha$-targeted siRNA (siRNA3 and siRNA4) or scrambled control siRNA (nsRNA). siRNA3 (a) and siRNA4 (b) has no effect on the radiosensitivity of HT 1080 cells in air, but increases radiosensitivity under hypoxic conditions.

Abbildung 6a und 6b. Klonogene Überleben in humanen HAT-1080Fibrosarkomzellen nach Behandlung der Zellen mit HIF-1 $\alpha$-targeted siRNA, bzw. Kontroll-siRNA (nsRNA) unter normoxischen bzw. hypoxischen Bedingungen $\left(20 \% \mathrm{O}_{2}\right)$. Das klonogene Überleben von humanen HAT1080-Fibrosarkom Zellen wurde nach Bestrahlung unter normoxischen $\left(20 \% \mathrm{O}_{2}\right)$ bzw. hypoxischen Bedingungen $\left(0,1 \% \mathrm{O}_{2}\right)$ bestimmt $(n=3$, Mittelwert \pm SE). HAT-1080-Zellen wurden 4 Stunden lang mit HIF-1 $\alpha$ targeted siRNA (a siRNA3, b siRNA4) und Kontroll-siRNA (nsRNA) vorbehandelt und anschließend 12 Stunden lang unter hypoxischen $\left(0,1 \% \mathrm{O}_{2}\right)$ bzw. aeroben Bedingungen $\left(20 \% \mathrm{O}_{2}\right)$ inkubiert. siRNA3 (a) and siRNA4 (b) hat keinen Effekt auf die Radiosensitivität von HAT-1080-Zellen unter Normoxie $\left(20 \% \mathrm{O}_{2}\right)$, erhöht aber die Radiosensitivität unter Hypoxie $\left(0,1 \% \mathrm{O}_{2}\right)$. 
Table 1. Survival fraction (SF) after irradiation at oxygen concentrations of $20 \%$ (air) or $0.1 \%$ (hypoxia $=$ hyp) following treatment with HIF- $1 \alpha$ targeted siRNA (siRNA3 and siRNA4) or scrambled control siRNA (nsRNA). Mean of $\mathrm{n}=3$; ${ }^{*}$ significant difference between HIF-1 $\alpha$-targeted siRNA (siRNA3/siRNA4) and control conditions (ns siRNA).

Tabelle 1. Survival Fraction (SF) nach Bestrahlung mit verschieden Sauerstoffkonzentrationen (20\% [air] oder $0.1 \%$ [hypoxia = hyp]) und Transfektion mit HIF-1 $\alpha$-targeted siRNA (siRNA3 und siRNA4). Mittelwert, $\mathrm{n}=3$; * signifikanter Unterschied zwischen HIF-1 $\alpha$-targeted siRNA siRNA3/siRNA4) und Kontrollbedingungen (ns siRNA).

\begin{tabular}{llll}
\hline & \multicolumn{3}{l}{ SF } \\
\hline & 2 Gy & 5 Gy & 10 Gy \\
\hline nsRNAair/siRNA3air & $0.497 / 0.515$ & $0.079 / 0.072$ & $0.002 / 0.001$ \\
nsRNAair/siRNA4air & $0.497 / 0.600$ & $0.079 / 0.083$ & $0.002 / 0.002$ \\
nsRNAhyp/siRNA3hyp & $0.974 / 0.530^{*}$ & $0.330 / 0.150^{*}$ & $0.061 / 0.033^{*}$ \\
nsRNAhyp/siRNA4hyp & $0.974 / 0.607^{*}$ & $0.330 / 0.211^{*}$ & $0.061 / 0.040^{*}$ \\
\hline
\end{tabular}

Table 2. Modified oxygen enhancement ratio (OER') derived from clonogenic survival curves after irradiation at oxygen concentrations of $20 \%$ (AIR) or $0.1 \%$ (hypoxia $=$ HYP) following treatment with HIF- $1 \alpha$-targeted siRNA (siRNA3 and siRNA4) where indicated. Mean \pm SEM of $n=3$; ${ }^{*}$ significant difference between HIF-1 $\alpha$-targeted siRNA (siRNA3/siRNA4) and control conditions ( $n$ s siRNA).

Tabelle 2. Eine modifizierte Oxygen Enhancement Ratio (OER') wurde abgeleitet aus den Überlebenskurven nach Bestrahlung mit verschieden Sauerstoffkonzentrationen (20\% [AIR] oder 0.1\% [Hypoxia = HYP]) und Transfektion mit HIF-1 $\alpha$-targeted siRNA (siRNA3 und siRNA4). Mittelwert $\pm \mathrm{SE}, \mathrm{n}=3$; ${ }^{*}$ signifikanter Unterschied zwischen HIF-1 $\alpha$-targeted siRNA (siRNA3/siRNA4) und Kontrollbedingungen (ns siRNA).

\begin{tabular}{|c|c|c|c|}
\hline $\begin{array}{l}\text { Survival } \\
\text { level }\end{array}$ & $\begin{array}{l}\text { OER' (HYPI } \\
\text { AIR) } \\
\end{array}$ & $\begin{array}{l}\text { OER' }^{\prime}\left(\mathrm{HYP}_{\text {siRNA3 }}{ }^{\prime}\right. \\
\text { AIR }_{\text {siRNA3 }} \text { ) }\end{array}$ & $\begin{array}{l}\text { OER' }^{\prime}\left(\text { HYP }_{\text {siRNA4 }}{ }^{\prime}\right. \\
\text { AIR }_{\text {siRNA4 }} \text { ) }\end{array}$ \\
\hline $10 \%$ & $1.68 \pm 0.08$ & $1.25^{*} \pm 0.17$ & $1.45 \pm 0.07$ \\
\hline $37 \%$ & $2.04 \pm 0.23$ & $1.12^{*} \pm 0.12$ & $1.21 * \pm 0.11$ \\
\hline $50 \%$ & $2.25 \pm 0.34$ & $1.06^{*} \pm 0.12$ & $1.11^{*} \pm 0.13$ \\
\hline
\end{tabular}

in the previous study and HIF-1 1 -targeted siRNA in the current study on all survival levels (50\%, 37\%, and $10 \%)$. HIF- $1 \alpha-$ targeted siRNA3 reduced the OER' compared to HT 1080 cells transfected with scrambled control siRNA (nsRNA), from 2.25 to 1.06 , from 2.04 to 1.12 and from 1.68 to 1.25 at the $50 \%$, $37 \%$, and $10 \%$ clonogenic survival levels, respectively. Treatment with HIF-1 $\alpha$-targeted siRNA4 reduced the modified oxygen enhancement ratio (OER') compared to HT 1080 cells transfected with scrambled control siRNA (nsRNA), from 2.25 to 1.11 , from 2.04 to 1.21 and from 1.68 to 1.45 at the $50 \%, 37 \%$, and $10 \%$ clonogenic survival levels, respectively. Chetomin, in comparison, reduced OER' from 2.02 to 1.27 , from 1.86 to 1.22 and from 1.49 to 1.06 at the $50 \%, 37 \%$, and $10 \%$ clonogenic survival levels, respectively. Taken together, HIF-1a-targeted siRNA and chetomin effectively radiosensitize hypoxic HT 1080 cells, whereas the radiosensitivity of normoxic cells remains unaffected [25]. The clongenic assay does not distinguish between the different types of cell death (i.e., cell cycle arrest, programmed cell death). Further experiments are necessary to understand completely the molecular aspects of hypoxia-induced radioresistance and the role of the HIF-1 pathway.
Nevertheless, these results indicate that selective inhibiton of the hypoxic HIF-1 pathway by downregulation of HIF1aprotein via HIF-1 $\alpha$-targeted siRNA treatment is as effective as treatment with chetomin as a small molecule blocking the HIF pathway. Chetomin, however, also had a cytotoxic effect in aerobic and, in particular, in hypoxic HT 1080 cells. In contrast HIF-1 $\alpha$-targeted siRNA had no cytotoxic effect in aerobic or hypoxic HT 1080 cells in the clonogenic assay compared with untreated HT 1080 cells or cells transfected with scrambled control siRNA.

One explanation for the apparently more specific action of the siRNA approach is the chetomin-induced disruption of the interaction of HIF-1 with the transcriptional coactivator p300 as a mechanism of action. HIF-1 is only one of many transcription factors requiring p300 as a cofactor, such as nuclear factor$\kappa \mathrm{B}$ and activating protein-1 [15]. Blocking p300 with chetomin may induce inhibition of activation of other transcription factors relevant to radiosensitivity. In contrast HIF-1 $\alpha$-targeted siRNA directly suppresses HIF-1a m-RNA expression and, therefore, the hypoxic accumulation of HIF-1a. This is one explanation why blocking HIF-1 activity with HIF-1 $1 \alpha$-targeted siRNA enhances radiosensitivity more selectively in hypoxic tumor cells than chetomin.

Yang et al. [39] could demonstrate that suppression of HIF-1 $\alpha$ by using small interfering RNA (siRNA) results in a decrease of cell proliferation and increase of chemosensitivity of pancreatic cancer cells in vitro and in vivo. RNA interference (RNAi) of HIF-1 is an effective strategy for inhibiting tumor cell growth, and both tumor and normal cells can be the target for RNAi-based anticancer treatment [27]. Furthermore HIF-1 $\alpha$ is an important component of the apoptotic signaling machinery and selective ablation of HIF-1a protein expression by RNA interference led to a reduction of caspase-3 activity and reduction in the number of apoptotic cells after hypoxia [19].

The success of HIF-1 inhibition in vivo depends on other factors of the tumor microenvironment such as glucose metabolism and $\mathrm{pH}[24,26]$ and potentially on the ability of a strategy to eliminate virtually all HIF-1 function as cell mixing experiments described by Williams et al. [37] indicated that $1 \%$ of cells with intact HIF-1 function within a tumor are sufficient to preserve tumor growth. Recently, Gillespie et al. [8] demonstrated that treating gliomas grown in mouse flank with siRNA against HIF- $1 \alpha$ by intratumoral injection resulted in a significant reduction in tumor growth. Nevertheless, intratumoral injection of small interfering RNA in tumors is not useful in all tumor entities. Another therapeutical approach blocking HIF- $1 \alpha$ activation is the use of short hairpin RNA (shRNA). Therapeutic application of shRNA, however, is also problematic as is it involves permanent changes in cellular DNA. Kung et al. [16] demonstrated that pharmacological inhibition of HIF activation with chetomin in vivo could slow tomor growth, suggesting that there is a therapeutic potential for inhibition of HIF function in vivo. 


\section{Conclusion}

Our results indicate that the selective inhibition of HIF-1 activation by using HIF-1 $\alpha$-targeted siRNA treatment reduces hypoxic radioresistance in vitro as effectively as a pharmacologic approach with chetomin as a small molecule blocking the HIF pathway. Pharmacological therapeutics targeting pathognomonic changes in cancer cells are potential canidatates for clinical use in cancer therapy and using siRNA to reduce HIF-1a levels in tumors may be of interest as a clinical treatment option in selected tumor entities.

\section{Acknowledgment}

This work was supported in part by a grant from the Deutsche Forschungsgemeinschaft (VO 871/2-3) to DV.

\section{References}

1. Aebersold DM, Burri P, Beer KT, et al. Expression of hypoxia-inducible factor1alpha: a novel predictive and prognostic parameter in the radiotherapy of oropharyngeal cancer. Cancer Res 2001;61:2911-6.

2. Bache M, Kappler M, Said HM, et al. Detection and specific targeting of hypoxic regions within solid tumors: current preclinical and clinical strategies. Curr Med Chem 2008;15:322-38.

3. Balducci M, Apicella G, Manfrida S, et al. Single-arm phase II study of conformal radiation therapy and temozolomide plus fractionated stereotactic conformal boost in high-grade gliomas: final report. Strahlenther Onkol 2010;186:558-64.

4. Comerford KM, Cummins EP, Taylor CT. c-Jun NH2-Terminal kinase activation contributes to hypoxia-inducible factor 1a-dependent Pglycoprotein expression in hypoxia. Cancer Res 2004;15:9057-61.

5. Comerford KM, Wallace TJ, Karhausen J, et al. Hypoxia-inducible factor-1dependent regulation of the multidrug resistance (MDR1) gene. Cancer Res 2002;15:3387-94.

6. Dellas K, Bache M, Pigorsch SU, et al. Prognostic impact of HIF-1 alpha expression in patients with definitive radiotherapy for cervical cancer. Strahlenther Onkol 2008;184:169-74.

7. Epstein AC, Gleadle JM, McNeill LA, et al. C. elegans EGL-9 and mammalian homologs define a family of dioxygenases that regulate HIF by prolyl hydroxylation. Cell 2001;107:43-54.

8. Gillespie DL, Whang K, Ragel BT, et al. Silencing of hypoxia-inducible factor1 alpha by RNA interference attenuates human glioma cell growth in vivo. Clin Cancer Res 2007;13:2441-8.

9. Griffiths EA, Pritchard SA, Valentine HR, et al. Hypoxia-inducible factor-1alpha expression in the gastric carcinogenesis sequence and its prognostic role in gastric and gastro-oesophageal adenocarcinomas. Br J Cancer 2007; 96:95-103.

10. Hall, EJ. Radiobiology for the radiologist. 4. ed. Philadelphia: Lippincott; 1994

11. Harris AL. Hypoxia - a key regulatory factor in tumour growth. Nature Reviews Cancer 2002;2:38-47.

12. Ivan $\mathrm{M}$, Kondo $\mathrm{K}$, Yang $\mathrm{H}$, et al. HIF alpha targeted for VHL-mediated destruction by proline hydroxylation: implications for $\mathrm{O} 2$ sensing. Science 2001;292:464-8.

13. Jaakkola P, Mole DR, Tian YM, et al. Targeting of HIF-alpha to the von HippelLindau ubiquitylation complex by O2-regulated prolyl hydroxylation. Science 2001;292:468-72

14. Kappler, Taubert $\mathrm{H}$, Holzhausen $\mathrm{HJ}$, et al. Immunohistochemical detection of HIF-1alpha and CAIX in advanced head-and-neck cancer. Prognostic role and correlation with tumor markers and tumor oxygenation parameters. Strahlenther Onkol 2008;184:393-9.

15. Khan ZA, Chakrabarti S.Cellular signaling and potential new treatment targets in diabetic retinopathy. Experimental Diabetes Research 2007;2007:31867.

16. Kung AL, Zabludoff SD, France DS, et al. Small molecule blockade of transcriptional coactivation of the hypoxia-inducible factor pathway. Cancer Cell 2004;6:33-43.

17. Lau SK, Boutros PC, Pintilie M, et al. Three-gene prognostic classifier for earlystage non small-cell lung cancer. J Clin Oncol 2007;25:5562-9.
18. Lövey J, Kenessey I, Rásó E, et al. Human recombinant erythropoietin-alpha increases the efficacy of irradiation in preclinical model. Magy Onkol 2007;51:53-61.

19. Malhotra R, Tyson DW, Rosevear HM, et al. Hypoxia-inducible factor-1alpha is a critical mediator of hypoxia induced apoptosis in cardiac $\mathrm{H} 9 \mathrm{c} 2$ and kidney epithelial HK-2 cells. BMC Cardiovascular Disorders 2008;8:9.

20. Matsuyama T, Nakanishi K, Hayashi T, et al. Expression of hypoxiainducible factor-1alpha in esophageal squamous cell carcinoma. Cancer Sci 2005;96:176-82.

21. Moeller BJ, Dewhirst MW. HIF-1 and tumour radiosensitivity. Br J Cancer 2006;95:1-5.

22. Semenza GL. Evaluation of HIF-1 inhibitors as anticancer agents. Drug Discov. Today 2007;12:853-9.

23. Shibata T, Giaccia AJ, Brown JM. Development of a hypoxia-responsive vector for tumor-specific gene therapy. Gene Ther 2000;7:493-8.

24. Sorensen BS, Alsner J, Overgaard J et al. Hypoxia induced expression of endogenous markers in vitro is highly influenced by $\mathrm{pH}$. Radiother Oncol 2007;83:362-6.

25. Staab A, Loeffler J, Said HM, et al. Effects of HIF-1 inhibition by chetomin on hypoxia-related transcription and radiosensitivity in HT 1080 human fibrosarcoma cells. BMC Cancer 2007;7:213.

26. Staab A, Löffler J, Said HM, Katzer A, et al. Modulation of glucose metabolism inhibits hypoxic accumulation of Hypoxia-inducible factor-1a (HIF-1alpha). Strahlenther Onkol 2007;183:366-73.

27. Takahashi Y, Nishikawa M, Takakura Y. Inhibition of tumor cell growth in the liver by RNA interference-mediated suppression of HIF-1alpha expression in tumor cells and hepatocytes. Gene Ther 2008,15:572-82.

28. TinkI D, Grabenbauer GG, Golcher $\mathrm{H}$, et al. Downstaging of pancreatic carcinoma after neoadjuvant chemoradiation. Strahlenther Onkol 2009;185:557-66.

29. Trastour C, Benizri E, Ettore F, et al. HIF-1alpha and CA IX staining in invasive breast carcinomas: prognosis and treatment outcome. Int J Cancer 2007;120:1451-8.

30. Vaupel P, Mayer A. Hypoxia in cancer: significance and impact on clinical outcome. Cancer Metastasis Rev 2007;26:225-39.

31. Vordermark D, Katzer A, Baier K, et al. M. Cell type-specific association of hypoxia-inducible factor-1 alpha (HIF-1 alpha) protein accumulation and radiobiologic tumor hypoxia. Int J Radiat Oncol Biol Phys 2004;58:1242-50.

32. Vordermark D, Shibata T, Brown JM. Green fluorescent protein is a suitable reporter of tumor hypoxia despite an oxygen requirement for chromophore formation. Neoplasia 2001;3:527-34.

33. Vordermark D, Brown JM. Endogenous markers of tumor hypoxia predictors of clinical radiation resistance? Strahlenther Onkol 2003;179:801-11.

34. Wang $G L$, Jiang $B H$, Rue EA, et al. Hypoxia-inducible factor 1 is a basic-helixloop-helix-PAS heterodimer regulated by cellular $\mathrm{O} 2$ tension. Proc Natl Acad Sci USA 1995;92:5510-4.

35. Welsh S, Williams R, Kirkpatrick L, et al. Antitumor activity and pharmacodynamic properties of PX-478, an inhibitor of hypoxia-inducible factor-1alpha. Mol Cancer Ther 2004;3:233-44.

36. Wolf $M$, Zehentmayr $F$, Niyazi $M$, et al. Long-term outcome of mitomycin C- and 5-FU-based primary radiochemotherapy for esophageal cancer. Strahlenther Onkol 2010;186:374-81.

37. Williams KJ, Telfer BA, Xenaki D, et al. Enhanced response to radiotherapy in tumours deficient in the function of hypoxia-inducible factor-1. Radiother Oncol 2005;75:89-98.

38. Wurstbauer $\mathrm{K}$, Weise $\mathrm{H}$, Deutschmann $\mathrm{H}$, et al. Non-small cell lung cancer in stages I-IIIB: long-term results of definitive radiotherapy with doses $\geq 80 \mathrm{~Gy}$ in standard fractionation. Strahlenther Onkol 2010;186:551-7.

39. Yang L, Kang WK. The effect of HIF-1 a siRNA on growth and chemosensitivity of Mia-paca cell line. Yonsei Med J 2008;49:295-300.

\section{Address for Correspondence}

Adrian Staab, MD

Paul Scherrer Institute

Center for Proton Radiotherapy

5232 Villigen PSI

Switzerland

Phone (+41/56) 310-3524, Fax -3515

e-mail: adrian.staab@psi.ch 